\author{
Michat Nowicki \\ Zakład Historii Wychowania \\ Wydziat Studiów Edukacyjnych UAM
}

\title{
Retoryka i historia w służbie wychowania w Polsce na podstawie analizy skryptu wykładów retoryki w Kolegium Jezuitów w Poznaniu z 1679 roku
}

\begin{abstract}
Rhetoric and History in the service of education in Poland on the basis of the script of rhetoric lectures at the College of the Jesuits in Poznan from 1679

The most important subject of the Old-Polish educational system was rhetoric, having roots in the tradition of the Ancient Rome. This statement is very important because of the fact of the orator's moral and patriotic duties. Owing to this, the lessons' focus was not only on technical aspects of rhetoric education but also on morality, religion and political knowledge.

The article is divided into two main parts. First of them is describing the role of the rhetorical education and the evolution of the connection between rhetoric and history which existed from the 1st century A.D. until the first decades of the 18th century, when history started separating from rhetoric.

The second part shows the historical education in practice on the example of the Jesuit College in Poznan. The analysis of this topic was based on the script of rhetoric lectures given in Poznań in 1679. With regard to this manuscript, it could be said that the most important aim of historical education was the patriotic and civil upbringing of the pupils, so that they could participate in political and cultural reality. The history taught in the College in Poznań was mainly connected with Poland and was rather practical.
\end{abstract}

Keywords: History of Education, Poznanian College Of Jesuits, School-System Of Poznań in 16th-18th Century, Secondary Schools, Historical Education, Moral Values

Historia w szkołach polskich okresu staropolskiego odgrywała rolę pomocniczą i rzadko tylko nauczana była jako odrębny przedmiot. Nie oznacza to jednak, że jej rola była ograniczona. Bynajmniej. Zawsze stanowiła ona doskonały nośnik treści dydaktycznych o charakterze kształcącym i wychowawczym, zwłaszcza w zakresie wychowania obywatelskiego. W artykule ukazano pomocniczą rolę historii w wychowaniu młodzieży szkolnej w okresie staropolskim w praktyce. W celu jak najdokładniejszego zobrazowania tego zjawiska materiał egzemplifikacyjny został zawężony do konkretnego przykładu 
- Kolegium Jezuickiego w Poznaniu, jednego ze znaczniejszych w Rzeczypospolitej. Do analizy zagadnienia szczególnie wnikliwie został wykorzystany jeden ze skryptów retorycznych, pochodzący z tego kolegium z 1679 r. ${ }^{1}$ Oczywiście wspomniana rola historii $\mathrm{w}$ procesie dydaktycznym jest już dobrze znana i opisana w historiografii ${ }^{2}$, tutaj jednak postanowiono przedstawić praktyczne zastosowanie tego przedmiotu w odniesieniu do konkretnej placówki oświatowej. Wprowadzeniem do właściwego problemu będzie pobieżny szkic ukazujący - rodzący się od czasów antycznych - związek historii z retoryka.

Już w odrodzeniu zauważono, że historia stwarza doskonałe warunki do kształtowania osobowości młodych ludzi. Jak zauważył Lech Mokrzecki, rolą historii w szkolnictwie staropolskim było ilustrowanie przez przykłady zasad tworzonych teoretycznie przez etykę. Filozofia i etyka miały przygotowywać zasady postępowania, natomiast historia obrazować je na odpowiednich przykładach. Co więcej, miała ona ukazywać słuszność propagowanych zasad i negatywne skutki ich odrzucania ${ }^{3}$. Jej rola w szkolnictwie była nieprzypadkowa. Oczywiste jest, że przykłady wykorzystywane podczas zajęć szkolnych były dobierane w ten sposób, aby osiagnąc jak największy efekt wychowawczy. Jednym z najistotniejszych zadań historii było zatem ukazywanie odpowiednich wzorców postępowania, a mianowicie sprawnej i etycznej działalności w dziedzinie politycznej, religijnej i gospodarczej ${ }^{4}$.

Jak wiadomo, centralne miejsce w staropolskiej edukacji zajmowało kształcenie retoryczne, co w dawniejszej historiografii było mocno krytykowane ${ }^{5}$. Unikając oceny tego zjawiska, warto zwrócić uwagę na kilka istotnych aspektów, które miały decydujący wpływ na formowanie się staropolskich programów kształcenia ${ }^{6}$. Świat renesansowy bardzo wcześnie zaczął odwoływać się do tradycji antycznej nie tylko w zakresie filozofii, literatury czy sztuki, ale także wychowania. W zakresie szkolnictwa zwieńczeniem edukacji była retoryka, sztuka zrodzona w Grecji a z czasem przeniesiona na grunt rzymski i tutaj dostosowana do potrzeb Imperium Rzymskiego. Chociaż cała teoria retoryczna zrodziła się w świecie helleńskim, szkoły renesansowe i te późniejsze korzystały z teorii rzymskich, co jest oczywiście zrozumiałe ze względu na wspólnotę językową. Decydu-

${ }^{1}$ Capitolium Copiose loquentis sapiae Avitis Poloniae Nobilitatum Stemmatibus Ceris fumosisque Maiorum illustre imaginibus Oratorum Calamo Ingenioque adumbratum ac Konarsciano in Academo Arhitectante Eloquentiae manu erectum ac reseratum Anno [...], 1679 Biblioteka Uniwersytecka w Poznaniu, rkps 588 I.

${ }^{2}$ W kontekście tej pracy warto przywołać przede wszystkim: K. Puchowski, Edukacja historyczna w jezuickich kolegiach Rzeczypospolitej 1565-1773, Gdańsk 1999.

${ }^{3}$ L. Mokrzecki, Poczatki nauczania historii w okresie I Rzeczypospolitej na tle praktyki stosowanej w szkolnictwie europejskim, w: Wokót staropolskiej nauki i oświaty. Gdańsk-Prusy Królewskie - Rzeczpospolita, Gdańsk 2001, s. 396.

${ }^{4}$ Warto jednak pamiętać, że realizowanie programu nauczania historii w okresie staropolskim, zwłaszcza do połowy XVIII w., uzależnione było każdorazowo od preferencji i merytorycznego przygotowania profesorów.

${ }^{5}$ Zob. np. J. Łukaszewicz, Historya szkót w Koronie i w Wielkiem Księstwie Litewskiem od najdawniejszych czasów aż do roku 1794, Poznań 1849, t. I-III.

${ }^{6}$ Autor świadomie używa tego generalizującego pojęcia, ze względu na zauważalną wspólnotę realizowanych celów kształcenia, metod i w dużym stopniu treści programowych. 
jące znaczenie mają tutaj dwie postaci: Cycero i Kwintylian. Zasługą pierwszego jest przede wszystkim stworzenie technicznego, łacińskiego języka retorycznego oraz zostawienie przebogatej spuścizny. Kwintylian natomiast w bardzo dokładny sposób przedstawił metodykę nauczania retoryki i scharakteryzował antyczny wzorzec mówcy. Warto się nad nim na chwilę zatrzymać, albowiem ukazuje on znaczenie kształcenia retorycznego w ogóle, także w czasach staropolskich. Otóż mówca, obok niekwestionowanych zdolności krasomówczych i odpowiedniego przygotowania technicznego, powinien także posiadać wszechstronną wiedzę, a nade wszystko być człowiekiem prawym (vir bonus) ${ }^{7}$. Wspomnijmy przy okazji, że zdaniem obu wspomnianych teoretyków wymowy niebagatelne znaczenie w edukacji przyszłego mówcy miała historia ${ }^{8}$. Jej rola bynajmniej nie ograniczała się, zdaniem Cycerona, do gromadzenia przydatnych przy układaniu mów przykładów. Szeroka erudycja powinna zapewnić przyszłemu mówcy znajomość natury ludzkiej, charakterystycznych dla człowieka wad: ambicji i namiętności, zalet: umiaru i skromności oraz takich aspektów jak ból i śmierć ${ }^{9}$. Cycero podkreślał także znaczenie znajomości prawa (w zakresie wojen, pokoju, społeczeństwa, podatków i ogólnie - cywilnego), tradycji oraz religii ${ }^{10}$, a także wskazywał na korzyści płynące ze studiów filozoficznych, do czego przywiązywał szczególną uwagę ${ }^{11}$. Przytaczanie w tym miejscu teorii Cycerona jest w pełni uzasadnione, ponieważ uczniowie szkół staropolskich zazwyczaj gruntownie się z nią zapoznawali, szczególnie w odniesieniu do dzieła $O$ mówcy. Znaczną popularnością cieszyły się także inne pisma, o charakterze filozoficznoetycznym, np. O powinnościach czy $O$ starości, które prezentowały uznawany za słuszny kanon cnót i obowiązków obywatelskich ${ }^{12}$.

Wykształcenie retoryczne w szkolnictwie staropolskim zapewniało przygotowanie młodzieży do życia publicznego, w zakresie tak kultury politycznej, jak i literackiej. Obok przekazywania uczniom przydatnej w przyszłej praktyce wiedzy i umiejętności oratorskich, przygotowywano młodzież szkolną do czynnego i biernego uczestniczenia $\mathrm{w}$ życiu kulturalnym epoki ${ }^{13}$. Uderzający $\mathrm{w}$ tym modelu jest pragmatyzm nauczania.

${ }^{7}$ M.F. Quintilianus, Institutionis oratoriae libri XII, wyd. L. Radermarcher, in Aedibus B.G. Tevbneri, Lipsiae 1959, s. 4: Oratorem autem instituimus illum perfectum, qui esse nisi vir bonus non potest, ideoque non dicendi modo eximiam in eo facultatem, sed omnis animi virtutes exigimus; s. 6: Sit igitur orator vir talis, qualis vere sapiens appellari possit, nec moribus modo perfectus [...] sed etiam scientia et omni facultate dicendi.

${ }^{8}$ Zob. np. M.T. Cycero, De oratore ad Q. fratrem, Oxoniae post 1696, p. 50, 58, 83 i in.

9 Ibidem, p. 21.

${ }^{10}$ Ibidem, p. 13: Quid? Leges veteres, moresque maiorum,: quid? Auspicia, quibus \& ego, \& tu, Crasse, cum magna Reipublicae salute praesumus: quid? Religiones, \& ceremoniae: quid? Haec jura civilia, quae jam pridem in nostra familia ulla eloquentiae laude versantur [...]; p. 19.

11 Ibidem, p. 14 i nn.

${ }^{12}$ T. Bieńkowski, Antyk w literaturze i kulturze staropolskiej (1415-1750). Główne problemy i kierunki recepcji, Wrocław-Warszawa-Kraków-Gdańsk 1976, s. 51.

${ }^{13}$ T. Bieńkowski, Kształtowanie publiczności literackiej w szkołach w Polsce w XVI $i$ XVII w., w: Publiczność literacka i teatralna $w$ dawnej Polsce, red. H. Dziechcińska, Warszawa-Lódź 1985, s. 39-49; idem, Szkolne wykształcenie retoryczne wobec wymogów praktyki (Uwagi o funkcji retoryki w Polsce w XVI $i$ XVII w.), w: Retoryka a literatura, red. B. Otwinowska, Wrocław 1984, s. 212 i n. 
Kształtował się on stopniowo w ciagu XVI i XVII w., rozbudowując renesansową wizję człowieka mocno osadzonego w wymiarze społecznym i silnie powiązanego ze światem natury (realistycznie pojmowanym i naukowo studiowanym) o wymiar spirytualistyczny, dając efekt pod postacią Sturmowskiej sapiens atque eloquens pietas wraz z równoczesną pragmatyzacją nauczania ${ }^{14}$. Jak zauważył Stanisław Bednarski, „tak pojęta wymowa była po prostu sztuką życia”, gdyż jej zadaniem było nauczenie ,orientowania się w sytuacji i znalezienia zawsze właściwego praktycznego stanowiska i właściwego poglądu na rzecz"15, co zresztą jest zgodne z przywołanymi wyżej zaleceniami Cycerona.

Przyglądając się XVI-wiecznej praktyce edukacyjnej w Polsce, dochodzimy do wniosku, że w pierwszej połowie tego stulecia historia pełniła głównie funkcję służebną wobec retoryki, gdzie elokwencja wysuwała się zdecydowanie na pierwszy plan w wychowaniu, historia natomiast dostarczać miała niezbędnej erudycji do wypełniania mów treścią. Obok tego zauważalna jest też jej dydaktyczna funkcja, wywodzona $\mathrm{z}$ potrzeby wyjaśniania omawianych w szkole treści, zaczerpniętych z dzieł klasycznych ${ }^{16}$. W drugiej połowie wieku jednak główne cele edukacyjne nieco się zmieniły i środek ciężkości przesunięty został znowu w kierunku wychowania moralnego, czy może szerzej - religijnego, jednakowoż - przy jednoczesnym uwzględnieniu potrzeb kształceniowych szlachty ${ }^{17}$. Zastosowanie historii z biegiem czasu ulegało rozszerzeniu na poetykę, literaturę, politykę, ale zwłaszcza na etykę, gdzie uwydatnia się rola historii jako skarbnicy różnorakich przykładów ${ }^{18}$. Już w XVI w. dostrzegalne jest wyraźne wykorzystywanie treści historycznych nie tylko dla celów egzemplifikacyjnych, ale także ściśle wychowawczych, $\mathrm{w}$ odniesieniu do wychowania moralnego czy patriotycznego. Wspomnijmy chociażby o historycznym dziele Klemensa Janickiego, w którym wyraźne są próby oddziaływania wychowawczego na czytelnika ${ }^{19}$. W XVII stuleciu pozycja historii w szkołach ugruntowała się, chociaż przeważnie zakres nauczania uzależniony był od profesora. Niekiedy jednak wyodrębniała się jako osobny przedmiot, często związany z retoryką ${ }^{20}$. Na terenie Poznania taka sytuacja miała miejsce w przypadku Akademii Lubrańskiego, co uchwytne jest dzięki wizytacji biskupa Wojciecha Tolibowskiego z 1660 r. $^{21}$

${ }^{14}$ M. Prejs, Humanizm potrydencki i nowy model kultury katolickiej (manieryzm czy barok?), w: Humanistyczne modele kultury nowożytnej wobec dziedzictwa starożytnego, red. M. Prejs, Warszawa 2010, s. 157.

15 S. Bednarski, Upadek i odrodzenie szkół jezuickich w Polsce, Kraków 1933, s. 185.

${ }^{16}$ Ibidem, s. 254.

${ }_{17}$ Warto zauważyć, że potrzeby te były celowo zaspokajane przez jezuitów już od pierwszych lat funkcjonowania ich szkół w Rzeczypospolitej, zob. L. Piechnik, Działalność jezuitów polskich na polu szkolnictwa (1565-1773), w: Jezuici a kultura polska, red. L. Grzebień i S. Obirek, Kraków 1993, s. 246 i n.

${ }^{18}$ L. Mokrzecki, Poczatki nauczania historii..., s. 390-403.

19 K. Janicki, Vitae Regum Polonorum elegiaco carminae descriptae, Cracoviae 1569. Jak podaje K. Puchowski, Edukacja historyczna..., s. 82. Vitae Regum Polonorum cieszyło się popularnością w szkołach jezuickich jeszcze w Oświeceniu.

${ }^{20}$ Było to zjawisko powszechne w skali kraju, zob. np. J. Taraszkiewicz, Edukacja historyczna w szkolnictwie pijarskim Rzeczypospolitej 1642-1773, Gdańsk 2011, s. 52 i n., 144.

${ }^{21}$ Akta wizytacji 1660-1663, Archiwum Archidiecezjalne w Poznaniu, sygn. AV 12, p. 112: Andreas Stanislaus Idecki orator legit mane duabus horis et duabus post meridiem Lectiones facultatis Oratoriae et Historiae. 
Program nauczania historii w Polsce ukształtował się w dużym stopniu dzięki inicjatywie biskupa Piotra Tylickiego, który polecił ułożyć na potrzeby głównie szkół parafialnych i katedralnych odpowiednie zalecenia. Stanisław Kot tymi słowami opisał postanowienia ustawy Modus Instituendae Iuventutis w interesującym nas zakresie: „Historyę można najpierw poznawać z Justyna, któy wywodzi początki rzeczypospolitej od stworzenia świata, za nim pójść ma Florus, jako streszczenie dziejów rzymskich Liwiusa, a nie wypada pominąć Curtiusa dla dziwnej potoczystości jęyka i wdzięcznego toku narracyi; dla starszych można by dodać Sallustiusa. Aby nie zostawiać odłogiem rzeczy ojczystych, wypada obok któego z wymienionych, przerabiać Janickiego poemat o dziejach polskich i historyę Herburta. Z lektury tej przykłady, mądre powiedzenia, czyny pamiętne, ma się wpisywać w książeczki dla pamięci”'22. Program ten, chociaż w zakresie realizacji uzależniony $\mathrm{w}$ dużym stopniu od przygotowania merytorycznego profesorów, daje nam ogóny obraz przekazywanych w szkołach treści historycznych.

Po tym dosyć ogólnym zarysie czas zająć się dokładniej miejscem historii w szkolnictwie jezuickim. Szczególnie godne uwagi są stosowane przez jezuitów metody nauczania, długo i precyzyjnie wypracowywane, opierające się na wcześniejszych osiągnięciach, począwszy od szkół Braci Wspólnego Życia ${ }^{23}$. Decydujące znaczenie dla ich ukształtowania miała jednak wieloletnia, uważna praktyka pedagogiczna jezuitów, którzy świadomie doskonalili metodyczne założenia swojego systemu szkolnego. Efektem wytężonej pracy była sławna Ratio studiorum, szczegółowo normująca metody pracy i zakres realizowanego w szkołach materiału ${ }^{24}$.

W ustawie tej zdobywanie historycznej erudycji przewidziano dopiero na moment po osiągnięciu odpowiedniego przygotowania językowego uczniów. Edukację historyczną należało rozpocząć w klasach humanistycznych (zwanych niekiedy poetyką). Erudycję powinno się zgłębiać przez lekturę mówców, historyków i poetów (,oczyszczonych" z wszelakich nieprzyzwoitości). Mówców miał reprezentować Cycero, z którego należało czytać mowy o charakterze moralnym oraz inne łatwiejsze, jak: Za prawem Maniliuszowym, W obronie poety Archiasza, O Marcellusie czy inne mowy skierowane do Cezara; historyków reprezentowali: Cezar, Salustiusz, Liwiusz, Kurcjusz i im podobni; poetów: Wergiliusz (z wyjątkiem Eklog i czwartej księgi Eneidy), wybrane ody Horacego, a także elegie, epigramaty i inna twórczość wybitnych przedstawicieli literackiego antyku. W odniesieniu do erudycji pojawiło się zastrzeżenie, że powinna ona pobudzać zdolności uczniów i dawać wytchnienie, a nie stać na drodze do opanowania języka. Stąd też nauczyciel powinien zachować umiar w tym zakresie ${ }^{25}$.

\footnotetext{
22 S. Kot, Szkolnictwo parafialne w Małopolsce XVI-XVIII w., Lwów 1912, s. 54.

${ }^{23}$ Zob. np. B. Natoński, Szkolnictwo jezuickie w Polsce $w$ dobie kontrreformacji, w: Wiek XVII - Kontrreformacja - Barok. Prace z historii kultury, red. J. Pelc, Wrocław 1970, s. 35.

${ }^{24} \mathrm{~W}$ niniejszej pracy wykorzystano wydanie: Ratio atque institutio studiorum Societatis Iesu, Romae 1616. Zob. też wyd. polskie: K. Bartnicka, red., Ratio atque insitutio studiorum SJ czyli Ustawa szkolna Towarzystwa Jezusowego (1599), Warszawa 2000; oraz publikację na temat tej ustawy: L. Piechnik, ,, Ratio studiorum ": fundament działalności edukacyjnej i naukowej jezuitów, w: Wkład jezuitów do nauki i kultury w Rzeczpospolitej Obojga Narodów i pod zaborami, red. I. Stasiewicz-Jasiukowa, Kraków 2004.

${ }^{25}$ Zob. przepisy w Ratio studiorum dla odpowiednich szkół i ich profesorów.
} 
Od strony praktycznej wyglądało to tak, że w pierwszym semestrze nauczyciel miał poświęcać ustaloną i wyodrębnioną część czasu na omówienie pisarza historycznego. Przez połowę semestru czas ten (pół godziny zegarowej) był dzielony z zagadnieniami sztuki metrycznej, następnie poświęcano go tylko historii. Wstawki erudycyjne mogły się pojawiać także w trakcie wykładu łacińskiego, wygłaszanego dla uczniów - należało to jednak czynić z umiarkowaniem i tylko w przypadku zaistnienia takiej potrzeby. Warto zwrócić uwagę na fakt, że o ile główny tok nauczania historii przewidziany był na klasy poetyki i retoryki, o tyle urywkowa wiedza z tej dziedziny zwykle przekazywana była już wcześniej, przy okazji nauki języków antycznych.

W szkole retoryki natomiast dzieła historyków i poetów miały służyć egzemplifikacji zastosowania określonego rodzaju stylu lub zasady retorycznej. Oprócz tego też należało poszerzać erudycję uczniów z „historii i obyczajów różnych narodów, z twierdzeń pisarzy i z każdej nauki”, ale dostosowanej do poziomu danej klasy. Najwygodniejszym czasem ku temu były dni wolne oraz soboty, w które czytano i objaśniano dzieła historyków, poetów bądź innych autorów. Mogły się tutaj pojawić takie treści, jak senat rzymski czy ateński, wojska tych państw, sztuka ogrodowa, stroje, stół, triumf, wyrocznia, z jedynym zastrzeżeniem - aby czynić to w sposób umiarkowany. Dodatkowo, pod koniec roku szkolnego, można było przedstawić autora, którego dzieła prezentowały większą wiedzę i różnorodność. Możliwość poszerzania erudycji historycznej pojawiała się także podczas wykładu reguł, gdzie oprócz egzemplifikacji można było sięgnąć po dodatkowe zagadnienia związane $\mathrm{z}$ historia, albo inną dziedzina, a także podczas wykładu z wybranej mowy. W tym przypadku nauczyciel winien przywoływać opinie ludzi mądrych na temat omawianej treści oraz czerpać materiał, którym można by ozdobić treść: z historii, mitologii i innych miejsc. Omówieniu tekstów pisarzy historycznych poświęcano także część wykładów greckich w pierwszym semestrze.

Duże znaczenie i silna pozycja historii w Ratio studiorum nie ulegają wątpliwości, chociaż jej rola, jak się zdaje, sprowadzona została w tej ustawie głównie do erudycyjnej i egzemplifikacyjnej. Może wpływ na ten stan rzeczy ma techniczny charakter odpowiednich ustępów ustawy, ponieważ jak wiadomo, ogólne cele wychowawcze szkół jezuickich dalekie były od czysto erudycyjnych. Warto zwrócić też uwagę na fakt, że erudycja służyć miała nie tylko bogaceniu treści przygotowywanych oracji, ale także stanowić swoistą rozrywkę i uprzyjemniać lekcje, a do tego też powodować pobudzenie umy$\mathrm{słu}^{26}$.

Z biegiem czasu historia zagwarantowała sobie stałe miejsce w szkołach Towarzystwa Jezusowego i już w XVII w. pojawiły się pierwsze postulaty wyodrębnienia zajęć z historii (Akademia Wileńska), odrzucone jeszcze przez generała zakonu. Póki co historia musiała nadal być wykładana w ramach innych przedmiotów humanistycznych ${ }^{27}$.

\footnotetext{
${ }^{26}$ Ratio atque institutio studiorum Societatis Iesu..., s. 122-128: Regulae Professoris Humanitatis; zob. też: S. Bednarski, Upadek i odrodzenie..., s. 254 i n.

${ }^{27}$ L. Mokrzecki, K. Puchowski, Pierwsi nauczyciele historii w szkolnictwie staropolskim, w: Nauczyciel historii. Ku nowej formacji dydaktycznej, red. M. Kujawska, Poznań 1996, s. 12; K. Puchowski, Edukacja historyczna..., s. 53 i n.
} 
Chociaż historia Polski obecna była tutaj już od końca wieku XVI, ograniczenie historii antycznej na korzyść współczesnej następowało powoli, wskutek stopniowej polonizacji kadr nauczycielskich ${ }^{28}$. W centrum zainteresowania znalazły się takie aspekty, jak: władca, ustrój, prawo, wojskowość, religia. Znacznie dynamiczniejsze przemiany w tym zakresie obserwujemy w XVIII w., jednak pozostaną one poza obszarem naszego zainteresowania ${ }^{29}$.

W związku z faktem, że historia stanowiła istotny element edukacji retorycznej, władze prowincji często zwracały uwagę na odpowiednie kształcenie uczniów w tym zakresie. Ludwik Piechnik przywoływał w tym kontekście jedno z poleceń, nakazujące kłaść szczególny nacisk na oddawanie się młodzieży „solidnemu studium historii, matematyki, geometrii i wymowy", przy czym władze kolegiów miały mieć staranie o zaopatrzenie szkół w odpowiednie podręczniki, pomocne w studiowaniu ${ }^{30}$.

Szkolnictwo jezuickie korzystało w procesie dydaktycznym lekcji retoryki z antycznych traktatów retorycznych: Arystotelesa, Cycerona i Kwintyliana oraz prac współczesnych, zwłaszcza popularnego w całej Europie kompendium Cypriana Soareza De arte rhetorica libri tres. Od połowy XVII w. jezuici w Rzeczypospolitej mieli do swojej dyspozycji także doskonałe kompendium retoryczne autorstwa Zygmunta Lauxmina, zatytułowane Praxis oratoria. Podręczniki te, chociaż de facto zawierały teorię retoryczna, przepełnione były rozmaitymi faktami historycznymi, wykorzystywanymi przy różnych okazjach. Ich zadanie polegało na ukazywaniu przykładów zastosowania określonej reguły retorycznej, jednak dobrane były w taki sposób, aby przy okazji przekazać dodatkową wiedzę rzeczowa, albo nawet wywrzeć pewien wpływ wychowawczy. Spójrzmy na przykład podręcznika Praxis oratoria ${ }^{31}$ :

- p. 15: Nam si potest ista pecunia sine Aratorum injura detrahi. Populus Romanus habeat: Praesertim in tantis aerarij angustijs.

- p. 16: Hoc capito QUIRITES omnes Gentes, Nationes, Provincias, Regna, Decemvirum ditioni, judicio, potestatique permissa et condonata esse dico. [...] Nisi ut decem Regem ararij, vectigalium, Provincarum omnium, totius Reipubl. Regnorum, liberorum populorum, orbis denique terrarum Domini constituantur, legis agraria simulatione atque nomine.

- p. 58: Conferte hanc pacem cum illo bello: hujus Praetoris adventum cum illius Imperatoris victoria: cujus cohortem impuram, cum illius exercitu invicto: hujus libidines

${ }^{28}$ K. Puchowski, Edukacja historyczna..., s. 57 i n.; o obecności elementów polskich w nauczaniu historii zob. T. Bieńkowski, , Bibliotheca selecta de ratione studiorum” Possevina jako teoretyczny fundament kultury kontrreformacji, w: Wiek XVII - Kontrreformacja....

${ }^{29}$ Zob. np. K. Puchowski, Edukacja historyczna..., s. 142 i nn.; L. Piechnik, Przemiany w szkolnictwie jezuickim w Polsce XVIII wieku, w: Z dziejów szkolnictwa jezuickiego w Polsce: wybór artykułów, red. J. Paszenda, Kraków 1994, t. 25, s. 191-194.

${ }^{30}$ L. Piechnik, Przemiany w szkolnictwie..., s. 207.

31 Z. Lauxmin, Praxis Oratoria. Sive Praecaepta Artis Rhetoricae, quae ad componendam orationem scitu necessaria sunt, Monachii 1658. Omówienie tego podręcznika pod względem retorycznym można znaleźć m.in. w: S. Bednarski, Upadek i odrodzenie..., s. 192 i nn. 
cum illius continentia: ab illlo, qui cepit conditas; ab hoc, qui constitutas accepit captas dicetis Syracusas.

- p. 60: Levia sunt haec in haec re crimina: metum virgarum Navarchus nobilissima Civitatis pretio redemit; humanum: alius ne condemnaretur pecuniam dedit; usitatum est. Non vult Pup. Rom. etc. [i komentarz autora:] Ex hoc fonte laudantur hostes, ut conillustrior Imperatoris virtus \& victoria appareat.

- p. 127

IN GENERE IUDICIALI

QUAESTIO. Virum Aristodomus Spartanus, quod e praelio ad Thermopylas solus incolumis evasisset, puniendis sit. Herod. Lib. 7.

STATUS Est conjecturalis.

PROPOSITIO ET CAUSA.

ACTORIS. Puniendus est Aristodomus, $n$. 5.

PATRONI: Non est puniendus. n. 7. [po czym następuje kilka stron dokładnej analizy zdarzenia].

- Rex Leonidas [...] necessarium esse videret, obsideri Thermopylas, ad arcendos a Graecia Barbaros.

Oczywiście są to tylko przypadkowo wybrane fragmenty tekstu, jednak już na ich podstawie można pokusić się o wyciągnięcie kilku drobnych wniosków. Autorzy podręczników dla zobrazowania wybranej reguły raczej nie tworzyli własnych przykładów, ale korzystali z bogatej spuścizny, głównie antycznej (chociaż zdarzają się bardzo ciekawe przykłady wykorzystywania tekstów współczesnych, bądź opisywania aktualnej sytuacji politycznej). Co więcej, przykłady były starannie dobierane, aby przy okazji ,,promować" wartości uznane za godne krzewienia w szkolnictwie. Przede wszystkim będą się one wiązały z cnotliwym życiem, oddaniem dla państwa i koniecznością dbałości o jego urządzenie i dobre funkcjonowanie (np. często pojawiające się sprawy skarbowości), poszanowaniem prawa czy zaletami życia ziemiańskiego (które było również bliskie Rzymianom). Oprócz tego ich zadaniem było ciąłe przybliżanie uczniom republikańskich zasad ustrojowych, podstawowych zasad prawa rzymskiego oraz, oczywiście, poszerzanie erudycji uczniów.

Warto zwrócić uwagę na fakt, że liczba materiałów, umożliwiających studiowanie roli historii w szkolnictwie jezuickim jest imponująca. Chodzi przede wszystkim o przygotowywane przez poszczególnych profesorów czy uczniów skrypty wykładów czy różnego rodzaju pomoce do jak najlepszego opanowania sztuki oratorskiej ${ }^{32}$. To w tych właśnie materiałach widoczna jest wielka rola historii $\mathrm{w}$ procesie dydaktycznym. Jeden $\mathrm{z}$ takich skryptów (wspomniane już wyżej Capitolium copiose loquentis) sporządzony został w Kolegium Jezuitów w Poznaniu w latach 1679-1680 i przeznaczony był dla szkoły retoryki. Z pewną ostrożnością można stwierdzić, że spisany został on przez profesora retoryki, na co wskazywać by mógł adres zamieszczony na jednej z pierwszej kart: ORATOR AUDITORI. W dalszej części autor tekstu zwraca się nie do pojedynczego czytelni-

\footnotetext{
32 Ostatnio wartościowe zestawienie prac szkolnych przygotował A.P. Bieś, Kadry nauczycielskie poznańskiego kolegium w XVI-XVIII wieku. Zarys problematyki, w: Wokól jezuickiej fundacji uniwersytetu z 1611 roku, red. R. Witkowski i D. Żołądź-Strzelczyk, Poznań 2011, s. 218-222.
} 
ka, ale do „kandydatów na mówców”. Przypuszczać więc możemy, iż mamy tutaj do czynienia z rzeczywistym skryptem wykładów, chociaż wyraźnie uporządkowanym treściowo, gdzie pewne partie tekstu zostały wyselekcjonowane.

Materiał ten jest dosyć obszerny i szczegółowy. Wyodrębnić można w nim kilka wyraźnych części. Zajmiemy się dokładniej pierwszą z nich, w której odnajdujemy poszczególne kwestie, związane z określoną częścią teorii retorycznej oraz wiedzy praktycznej. Wstawki erudycyjne najczęściej są obszerne, dzielone na Eruditio profana i sacra, chociaż podział ten nie do końca oddaje treść, która ukrywa się pod poszczególnymi fragmentami. Treść natomiast jest związana $\mathrm{z}$ historią najważniejszych polskich rodów herbowych i przy okazji z historią Polski ${ }^{33}$. Partie herbowe uzupełniane są opisami rozmaitych emblematów, które mogły posłużyć przy budowaniu narracji (Symbola). Obok tego pojawiają się wyodrębnione części nazwane Discursus politicus, omawiające wybrane zagadnienia związane z funkcjonowaniem państwa polskiego, jak chociażby: znaczenie szlachectwa, wolności, sprawy skarbu królewskiego, problematycznych kwestii dotyczących elekcji królewskich itd.

Na pierwszych kartach książki znajdujemy przykład wykładu, dającego przydatne informacje do ułożenia mowy na okoliczność herbową. W pierwszej kolejności przedstawiono herb Habdank. Historię jego nadania opisano tutaj w szerokim kontekście dziejowym, przywołując odpowiednich władców Polski z powołaniem się na przekaz Długosza. Po omówieniu legendarnych dziejów kraju wraz z postacią Kraka i faktem zabicia smoka na górze Wawel przedstawiono legendę herbową związaną z hołdem lennym w Krzyszkowie ${ }^{34}$ :

Anno 1109 vocatum est hoc stemma ex occasione Ioannis Skarbek Comitis a Boleslao Crivoustio ad Henricum Imperatorem nuntij cui Imperator ad debellandam Poloniam thesauros paratos ostendit, sed generos [...] legatus detractum digito annulum iniecit thesauro. Aurum inquiens addamus auro. Cui Caesar respondit Habdank id esse gratias habeo.

Po dokładnym opisie graficznym omawianego herbu w ramach sekcji Eruditio profa$n a$ przywołano związane z nim wiersze, w tym autorstwa Macieja Sarbiewskiego. Następnie autor, nawiązując do znajdującej się w herbie litery „W”, wyjaśniał powstawanie symboliki herbowej ${ }^{35}$ :

Lacedemonii scutis suis litteram L inscribebant. Messenij literam M. Romani omnia signa militaria prima litera nominis Ducis sui notabant. Ita Alexander ab Alexandro lib: 4 Cap: 2 ut Cingunt Poetae Mercurium primum fuisse inventorem sermonis humani et literarum [...]. Traianus Imperator glorabatur sui nominis literas plurissimas fuisse. Hercules longioris peregrinationis causam dabat. Nomen Herculis quaero Ego a circumstantia stemmatis huius mentionem feci Illsmi Fundatoris Adami Konarski sed erige tandem sacris intumulatum cineribus caput Illrsime et Rndissime Antistes Adame Konarski etiam te vel in emortuali meta manet

${ }^{33} \mathrm{O}$ wadze tematyki heraldycznej w nauczaniu w szkołach jezuickich, zob. K. Puchowski, Edukacja historyczna..., s. 62-64.

34 Capitolium Copiose loquentis..., f. 7.

35 Ibidem, f. $7 \mathrm{v}$. 
laurea imo primas supremasque unam in flectemus in Coronam, qua Infulatum verticem omnium compendium decorum coronemus.

Powyższy przykład, jak obserwujemy, ma w zasadzie przede wszystkim wartość erudycyjną. Jedyne chyba co możemy tutaj dodać, to zasługa polegająca na wskazywaniu związku głównych rodów herbowych z odległą tradycją narodową, co z pewnością budowało poczucie jedności narodowej (stanowej). Przy okazji trzeba podkreślić, że o ile dzisiaj wartość wiedzy genealogicznej może wydawać się niezbyt duża, o tyle w ówczesnej sytuacji politycznej i kulturalnej miała ona niebagatelne znaczenie i stanowiła istotny element wykształcenia. Jak zauważył Sławomir Baczewski, od schyłku XVI stulecia mamy do czynienia z przeniesieniem punktu ciężkości w dyskusji nad szlachectwem z problemu obowiązków szlachty wobec Rzeczypospolitej na dyskurs heraldyczno-genealogiczny. Podejmowanie tej problematyki miało za zadanie ukazywać niezmienność oraz ciagłość szlachectwa, co osiaggano przez wskazywanie zasłużonych przodków i ich współczesnych spadkobierców ${ }^{36}$ oraz legitymizować pozycję szlachty w państwie i społeczeństwie ${ }^{37}$.

Z perspektywy wychowawczej znacznie ciekawiej prezentują się „dyskursy polityczne". Pierwszy z nich dotyczy szlachectwa polskiego (de Polona Nobilitate), które zdefiniowane zostało jako świetność rodu otrzymana z rąk władcy za wyróżnianie się wspaniałymi cnotami. Cnota została nierozdzielnie związana ze szlachectwem, i to zarówno cnota moralna, jak i rycerska ${ }^{38}$. Wywiedziono stąd obowiązki szlachty: obrona Rzeczypospolitej oraz służenie jej radą ą $^{39}$ a także przeprowadzono dowodzenie słuszności wydzielenia spośród społeczeństwa grupy szlacheckiej. Wśród argumentów pojawiło się m.in. przekonanie, że równość mieszkańców mogłaby doprowadzić do zgubnej dla państwa rywalizacji. Z drugiej strony, jak dowodzono, występowanie szlachectwa w takich imperiach, jak tureckie czy chińskie przyczynia się do znacznego rozkwitu tych państw. Podobnie u Szwajcarów i Holendrów. Oprócz tego przywołano też szereg przykładów z odleglejszej historii. Co ciekawe, pojawia się tutaj także argument, że równość wszystkich stanów została odrzucona przez Jana Bodina w trzeciej księdze dzieła o Rzeczypospolitej. Szlachectwo było również uprawomocnione w oczach autora przez starożytność $^{40}$ :

Probatur antiquitate nobilitatis. Nobilitas semper fuit in omni Republica bene constituta. Nam apud Israelitas erant Principes Nobiles et Optimates. Apud Aegyptios fuerunt varij Principes, apud Persos et Medos mali. Habuit Macedonia Nobiles, habuit Graecia, Athenisque ipsis Nobilibus Magistratum cura demandabatur. In Germania Imperij fulcrum Nobilitas. In Gallia

${ }^{36}$ S. Baczewski, Szlachectwo. Studium z dziejów idei w piśmiennictwie polskim. Druga połowa XVI wieku - XVII wiek, Lublin 2009, s. 144, 148 i nn.

37 Ibidem, s. 238.

38 Por. ibidem, s. 218.

${ }^{39}$ Capitolium Copiose loquentis..., f. 8 i n.: Primum igitur et principale Nobilitatis fundamentum virtus est, eaquem aut civilis aut martialis; ideo enim aliquis creatus nobilis quia hostem fortiter oppressit; aliquodque opus strenuum est aggressus, vel quia consilio Rempublicam iuvit et erexit.

40 Ibidem, f. 9. 
Nobiles bella gerunt et Rempublicam administrant. Quid de nostra dicendum Polonia quae nisi

Nobilitatem habuisset iam pridem suis involuta ruinis incinerata cladibus periisset.

Argumentacja w skrypcie jest znacznie obszerniejsza, nie ma potrzeby jednak przywoływać jej in extenso. Zauważmy, że przykłady historyczne zostały tutaj wprowadzone w celu wzmocnienia argumentacji, dzięki zasadzie dużej wartości tradycji. Podejście charakteryzujące się szacunkiem dla przodków i przeszłości, a także pewnym respektem wobec nich - umożliwiało oddziaływanie wychowawcze na uczniów za pośrednictwem właśnie historii.

Omawiany skrypt prezentuje także historyczny wywód kształtowania się prawa szlacheckiego, począwszy od statutów wiślickich Kazimierza Wielkiego, normujących naganę szlachectwa, z krótkim określeniem zasad. Następnie pojawia się przywilej piotrkowski Zygmunta III, potwierdzający przywileje szlacheckie oraz nadający swobody ekonomiczne w odniesieniu do szlacheckich poddanych oraz tegoż, nadający szlachcie wyłączne prawo do piastowania kanonii i prałatur w kościołach katedralnych. Oprócz tego omówiono przywileje dotyczące nietykalności szlacheckiej, wyłącznego prawa do pełnienia funkcji senatorskich, wolności ekonomicznych oraz prawa do elekcji królewskiej. Widoczne jest, że młodzież podczas zajęć była uczulana na wyjątkowość stanu szlacheckiego (Pretium Polonae Nobilitatis), dla potwierdzenia czego użyto anegdoty ukazującej troskę cesarza Augusta o zapewnienie swojej córce odpowiedniego męża ${ }^{41}$. Uderzająca jest w tym przypadku wielka praktyczność historii dla edukacji młodzieży szlacheckiej. Otrzymywała ona nie tylko wiedzę o prawach przynależnych swojemu stanowi, ale także informacje, gdzie szukać ich potwierdzenia.

Przedmiotem kolejnego dyskursu była polska wolność. Zaczyna się on od ważkiego stwierdzenia, że wolność jest droższa od wszelakich rzeczy, dla Polaków zaś nawet od życia. Po ogólnym wstępie następuje swoista apologia kształtowania się polskiej wolności jako ewenementu ze względu na stopniowy i pokojowy proces, po czym autor przywołuje najważniejsze postanowienia w tej kwestii. Wspomniano tutaj działania Kazimierza Wielkiego, Ludwika Węgierskiego i Władysława Jagiełły. Zakończeniem tego zagadnienia jest dość obszerny opis zarzutów stawianych „złotej wolności” i i argumentów przeciwnych ${ }^{42}$.

Obok treści polityczno-społecznych w tekście pojawiają się także interesujące zagadnienia służące edukacji ekonomicznej. W tym kontekście warto przywołać wykład dotyczący skarbca królewskiego: Thesaurus maximum Regnorum fulcrum ac praesidium. Quare Henricus Imperator non armis se Poloniam debellaturum iactabat, non ferro vastaturum sed auro thesauroque, quem iactabundus Poloniarum Legato praesentabat ${ }^{43}$. Kontynuując, autor wykładu stwierdzał, że Rzeczpospolita nie może funkcjonować bez skarbca, podobnie jak złoto nie może się obyć bez żelaza i na odwrót. Sine thesauro Respublicam corpus ex anima est. Pojawia się zaraz przykład księcia Bolesława, który

\footnotetext{
41 Ibidem, f. $9 \mathrm{v}-10 \mathrm{v}$.

42 Ibidem, f. $14 \mathrm{v}$ i nn.

43 Ibidem, f. 22.
} 
pokonanym rycerzom miał pokazywać bogactwa swojego skarbca. Dalej poruszone zostało zagadnienie przechowywania całego skarbu państwowego w jednym miejscu. Za argument przeciwko takiej praktyce posłużył przykład biblijnego króla Ezechiasza, który pokazawszy swoje skarby legatom asyryjskim miał pobudzić Sennacheryba do wojny. Następnie przywołano praktyki Starożytnego Egiptu, gdzie nie miano gromadzić skarbów ze względu na brak zagrożenia zewnętrznego, co z kolei umożliwiało im wydatkowanie funduszy na rozmaite budowle. Obszerniej omówiono argumenty przemawiające za gromadzeniem skarbu i odpowiednim staraniem wokół niego. Odwołano się np. do dziejów Sparty, Rzymu i Genui. Przywołano postaci Romulusa, Katona i cesarza Augusta, który własnoręcznie miał sporządzać rachunki przychodów i wydatków Cesarstwa. Zwrócono uwagę na uprawę roli w Egipcie i płynące stąd zyski dla skarbu państwa. Ukazano też przykład króla Francji Ludwika (prawdopodobnie chodzi o Ludwika VII Młodego), który za panowania Cesarza Alfonsa (Alfons VII Imperator), przybywszy do Toledo miał zachwycić się tamtejszymi wspaniałościami i przepychem, wynikającymi z dbałości o skarbiec, niespotykanej w Europie ani w Azji ${ }^{44}$.

Uzupełnieniem dziełka jest godny uwagi zbiór sentencji wybranych z dzieł historycznych i retorycznych na rozmaite tematy: timor, licentia puniendi mali, suprema potestas, animi victoria, sapientia est vincere seipsum, belli signum timor, iniuria, „niepodobna rzecz wszystkiego wypisać" (sic!), pax semper potior. Przykłady te, w bardzo znacznej ilości, wskazują z kolei przede wszystkim na wagę moralności, co poniekąd było zaniedbywane w głównej części pracy. Wiadomo przecież, że wychowanie moralne czy religijne było w centrum zainteresowania szkół jezuickich. W kontekście natomiast omawiania roli wychowania historycznego w tym Kolegium, wskazane by było zwrócić także uwagę na wybrane sztuki sceniczne poznańskiego teatru szkolnego. Szczególnie tutaj bowiem uwydatnia się ogromna rola historii najnowszej w kształtowaniu sylwetek moralnych i patriotycznych młodzieży szkolnej ${ }^{45}$.

Rola narracji historycznej w nauczaniu szkolnym była wieloraka. Zdecydowanie na pierwszym miejscu plasuje się w tym konkretnym przypadku wychowanie patriotyczne i ogólniej - obywatelskie, dające uczniom solidną podstawę do funkcjonowania w ówczesnej politycznej i społecznej rzeczywistości. Gdy dodamy do tego jeszcze kompetencje uczniów w zakresie przygotowania językowego i literackiego - otrzymujemy bardzo ciekawą sylwetkę absolwenta ówczesnej polskiej szkoły. Uczniowie w ramach dyskursów politycznych otrzymywali wiedzę z zakresu przywilejów stanowych, ale także obowiązków ciążących na szlachcie. Zauważmy, że historia była także środkiem prze-

\footnotetext{
44 Ibidem, f. 22-23.

45 Zagadnienie szkolnego teatru jezuickiego posiada bardzo bogatą literaturę, stąd też w tym miejscu problem został tylko zasygnalizowany, zob. m.in. J. Poplatek, Studia z dziejów jezuickiego teatru szkolnego w Polsce, Wrocław 1957; J. Okoń, Dramat i teatr szkolny. Sceny jezuickie XVII wieku, Wrocław 1970; J. Okoń, Na scenach jezuickich $w$ dawnej Polsce, Warszawa 2006; B. Judkowiak, Teatr i dramat jezuitów, „Kronika Miasta Poznania" 2000, nr 3, s. 22-42; B. Judkowiak, Kilka uwag na temat teatru poznańskich szkót jezuickich w kontekście ich starań o prawa uniwersyteckie, w: Wokót jezuickiej fundacji...; oraz ostatnio: M. Nowicki, Edukacyjne walory publicznych występów poznańskiej młodzieży szkolnej w XVI-XVIII wieku, „Studia Edukacyjne” 2011, t. 15 , s. $183-195$.
} 
kazu realnej wiedzy dotyczącej przeszłości antycznej i polskiej, w tym także szeroko rozumianej kultury i różnorakich zagadnień ustrojowych. Zgromadzona w szkole i dzięki własnej lekturze dzieł historycznych wiedza stanowić miała w przyszłości podstawę do praktykowania w życiu publicznym sztuki oratorskiej oraz czynnego i odpowiedzialnego zarządu państwem polskim. Zauważmy dodatkowo, że na erudycji opierały się przedstawienia teatralne, dialogi szkolne czy okolicznościowe przemówienia. Bez odpowiedniego przygotowania szlachcic nie byłby w stanie uczestniczyć w życiu kulturalnym swojej epoki i bynajmniej nie chodzi tutaj wyłącznie o kulturę w znaczeniu elitarnym, ale wręcz „popularnym”, w zawężeniu oczywiście do stanu szlacheckiego. Doskonałym przykładem tego ważnego wówczas zadania będą erudycyjne zbiory dotyczące polskich herbów, zawierające legendy herbowe, opisy herbów, emblematy (np. jastrząb między kolumnami, jastrząb pozbawiony szponów itd. wraz z odpowiednio dobranymi sentencjami), ale przede wszystkim zbiory historycznych faktów pomocnych przy układaniu mów na okoliczność herbową zarówno o charakterze świeckim, jak i sakralnym (eruditio sacra et profana).

Młodzi ludzie, zdaje się, dzięki „aktywnemu” poznawaniu przeszłości (przez sztuki sceniczne czy układanie mów lub krótszych utworów literackich) zdobywali bardzo gruntowne wykształcenie historyczne i chociaż przez większość okresu staropolskiego nie uczęszczali na odrębne zajęcia $\mathrm{z}$ historii, posiadali o wiele większe kompetencje w tym zakresie niż współczesna nam młodzież. Na szczególną uwagę w tym względzie zasługuje historia współczesna, której poświęcano bardzo dużo uwagi, zwłaszcza w odniesieniu do sytuacji politycznej państwa polskiego. Warto w tym miejscu zauważyć, że zdecydowana większość treści omawianego dzieła koncentruje się na sprawach Polski i jej dziejów. Historia powszechna ma co prawda tutaj istotne zadanie, ale jest ono zwykle ograniczone do dostarczania argumentów przemawiających za wybraną tezą, albo po prostu do egzemplifikacji wybranych zagadnień. 